\title{
Heidegger among the Theologians
}

\section{Preface to the "Quadrige" Edition of Heidegger et la question de Dieu}

\author{
Jean-Yves Lacoste \\ Clare Hall, University of Cambridge, Cambridge, UK \\ jean-yves.lacoste@wanadoo.fr
}

It will be agreed that Martin Heidegger's brief studies in theology at Freiburgim-Breisgau afforded him a major advantage: it allowed for an intensive reading of Edmund Husserl's Logical Investigations. ${ }^{1}$

Not only that, of course. Freiburg's (Catholic) Theology Faculty at the time included the highly esteemed professor Carl Braig. Professor of Dogmatics but also a philosopher, Braig had published a treatise on ontology in 1896, which the high schooler Heidegger had no doubt read. ${ }^{2}$ In this work Braig clearly distinguished ens and esse, and emphasized a citation of the Itinerarium of Bonaventure, a favorite author of Braig's, one whom he probably would have had his student read. The climate was one of neo-Thomism, but Braig was a product of the Tübingen school, a guarantee of moderation: the theoretical Bible of neoThomism, Kleutgen's Philosophie der Vorzeit and Theologie der Vorzeit, do not seem to have been imposed on young theologians of Freiburg. On the other hand, the climate of the modernist crisis, and the prospect of one day having to take the Anti-modernist Oath, certainly played a role in Heidegger's deserting the Faculty of Theology for the Faculty of Philosophy. However, he left with the reputation of a future brilliant disciple of the philosophy which dominated the Catholic world - in 1913-1914 he even would obtain a grant of $1000 \mathrm{RM}$, offered by a foundation confident that he would "remain faithful to the spirit of Thomist philosophy."3

1 Originally published as "Préface à l'édition 'Quadrige,'” in Heidegger et la question de Dieu (Paris: Presses Universitaires de France, 2009), pp. 7-28, hereafter HQD.

2 Vom Sein: Abriss der Ontologie (Freiburg: Herder, 1896). See Richard Schaeffler, Die Wechselbeziehungen zwischen Philosophie und katholischer Theologie (Darmstadt: Wissenschaftliche Buchgesellschaft, 1980), pp. 229-230.

3 See H. Ott, Martin Heidegger. Unterwegs zu seiner Biographie (Frankfurt-New York: Campus, 1988), pp. 79-80, translated by A. Bluden as Martin Heidegger: A Political Life (London: Athlone, 1993). 
Heidegger's theses for Promotion and Habilitation bear the marks of these brief theological studies. His critique of psychologism was evidently born out of contact with Husserl - but this anti-psychologism joined the ritual antisubjectivism of Neo-Scholastic philosophy. The choice of a pseudo-Duns Scotus as the subject of his Habilitation is further proof of his already existing interest in medieval thought: it could be said that with this new thesis Heidegger had assigned himself the goal of "giving a new life to medieval philosophy with the help of phenomenology learned from Husserl"4 - and Erich Przywara, in fact, saw Heidegger as an "adherent of scholastic Scotism." Heidegger would not have accepted this judgment, and would (later) declare his refusal of a "Catholic phenomenology" on the same terms he would refuse a "Protestant mathematics." 6

Throughout the years, these theological interests remained. He never carried out an anticipated project comparing Thomas Aquinas and Duns Scotus. The ongoing study of Luther was of primary importance. Late to be rediscovered, Luther's commentary on the Epistle to the Romans had been published in 1908, and as a student Heidegger had read it avidly: ${ }^{7}$ the young Luther would remain on Heidegger's desk for a long time, as did Kierkegaard and Pascal (although the latter was of lesser importance to him). The reading of Schleiermacher was essential, at a time when Barth and his group had definitively made a break with it. Consequently, on August 1, 1917, Heidegger delivered a talk on "the religious" in the Second Discourse of Schleiermacher to a circle of students. The publication of R. Otto's book The Idea of the Holy at this same time could not have left him indifferent. Husserl had read the book before Heidegger, and probably advised him to do the same, and had read it badly enough to become enthusiastic about the "phenomenology of religion" which he thought he perceived in it. Another reading common to Husserl and Heidegger was that of Meister Eckhart. Husserl was fascinated, Heidegger deeply interested. Other mystics had appeared in the following years: Bernard of Clairvaux, in whom Heidegger had clearly perceived the overdetermination of fides by humilitas; ${ }^{8}$

4 K. Baier, "Heidegger und das Mittelalter," in Helmuth Vetter, ed, Heidegger und das Mittelalter (Frankfurt: Peter Lang, 1997), p. 13.

5 In und Gegen (Nuremberg: Glock und Lutz, 1955), p. 6 o.

6 GA 24, p. 28.

7 Luthers Vorlesung über den Romerbrief, 1515/1516, J. Ficker, ed, (Leipzig: Dietrich, 1908). Cf. K. Kardinal Lehmann, “'Sage, was Sache ist': der Blick auf die Wahrheit der Existenz. Heideggers Beziehung zu Luther," in N. Fischer and F.W. von Herrmann, eds, Heidegger und die christliche Tradition (Hamburg: Meiner, 2007), pp. 149-166.

8 See Remi Brague, "L' anthropologie de l' humilité," in R. Brague, ed, Saint Bernard et la philosophie (Paris: Presses Universitaires de France, 1993), pp. 129-152. 
Johannes Johann Tauler and Henry Suso; Teresa of Avila entered the small world of phenomenologists because of the importance she occupied in the Nachlass of Reinach, the former assistant of Husserl in Göttingen, who died at the front.

That's not all. If the post-war years theologically belonged to "dialectical theology," Adolf Harnack and his Lehrbuch der Dogmengeschichte were probably more useful to Heidegger than Barth (for whom he never showed great respect). ${ }^{9}$ Was Christianity led astray when it entered contact with Hellenism? This was the thesis of Harnack. Heidegger was never really interested in Christian doctrines. But if the hellenization of doctrines corresponded to a hellenization of Christian experience, then a task imposed itself on the privatdozent Heidegger: to find a way of accessing this primitive Christian experience. While it was unknown to participants at the 1979 colloquium, Heidegger's 19201921 course analyzes the most ancient Christian document we possess, the first epistle of Paul to the Thessalonians, in order to clear the way to this experience, primordially as an experience of time. Here again, one sees the influence of Nietzsche's friend Overbeck: the time that Christianity lives out, it lives out in an eschatological perspective. It can be presumed as well that the pamphlet of J. Weiss against liberal theology did not go unnoticed by Heidegger. ${ }^{10}$ And it must be added that the Bible used by Heidegger did not include the Old Testament. Like every first-year student, he learned a bit of Hebrew. The experience of Israel on the other hand, whether the historical, prophetic, or wisdom tradition, always remained foreign to him.

The arrival of Heidegger at Marburg as an "extraordinary" professor was an occasion that formed a friendship which would last fifty years. Heidegger did not bond with any of his philosophical colleagues - even though he could have found a dialogue partner in the person of N. Hartmann, who was at the time drawing near to phenomenology. On the other hand, he bonded with a theologian and exegete, R. Bultmann, and even Heidegger's short-lived public Hitlerism could do nothing to shake this friendship (Bultmann contented himself with replying to the "Rector's Inaugural Address" with an hour-long class on the "Task of Theology in the Present Situation,"11 in a tone which was certainly

9 Tubingen: Mohr Siebeck, 19o9; translated by N. Buchanan, History of Dogma (Boston: Little Brown and Company, 1901).

10 Johannes Weiss, Die Predigt Jesu vom Reiche Gottes (Göttingen: Vandenhoeck \& Ruprecht, 1892; 2nd Rev. Ed. 190o), trans. by R.H. Hiers and D.L. Holland as Jesus' Proclamation of the Kingdom of God (Philadelphia: Augsburg Fortress Publishing, 1971).

11 See Martin Heidegger - Rudolf Bultmann, Briefwechsel 1925-1975. Andreas Großman and Chrisof Landmesser, eds, (Tübingen-Frankfurt: Mohr Siebeck, 20o9), pp. 276-286. 
cautious, but not lacking in courage. ${ }^{12}$ This friendship can be accounted for through their shared affinities. As a student of Wilhelm Herrmann, Bultmann had been imbued with an interest in Christian experience rather than Christian doctrines. A fellow traveler with Barth, he, too, had recognized the eschatological character of Christian experience: any interest in a "salvation history" was excluded, and the historiological (Historisch) - the object of historical science - was abandoned on the roadside in favor of the historical (Geschichtlich). Shortly before Heidegger's arrival, Bultmann had given a perfect summary of his conception of theology: "the object of theology is God, and theology speaks of God to the extent that it speaks of man as he stands before God, thus, starting from faith."13 The two men thus did not lack common subjects of preoccupation. The years at Marburg were those where Heidegger prepared Being and Time. Bultmann and he met to read the Gospel of John together, as the former was preparing his commentary on the subject. Heidegger was a regular at Bultmann's famous "Graeca" - weekly gatherings where participants read Greek texts together, from the classics to Fathers of the Church. Bultmann frequented Heidegger's courses, and the theoretical articles he published during this period bore the mark of this frequentation. Heidegger, likewise, participated in Bultmann's seminars and expressed his thinking on Luther in a language that Bultmann could have made his own. "The object of theology is God; its theme is man in the 'how' of his situation before God ... The fundamental work of theology is thus to interpret man's being in the world in such a way that he could access God starting from this being."14 These commentaries on Luther gave Heidegger the opportunity to yet again distance himself from his native Catholicism: in the same seminar, he notes that every "vision" of God is transformed by Paul into the hearing of a call. ${ }^{15}$

As the first audience of Being and Time, Bultmann found in it a reason to break with the "theology of crisis": a reading of unbelieving (or not yet believing) existence which served as an (existential) bedrock to an (existentiell) reading of believing existence. On March 22, 1928, Bultmann wrote to Heidegger that his departure from Marburg would be a "heavy loss for theology."16 Heide-

\footnotetext{
12 Ibid.

13 "Die liberale Theologie und die jüngste theologische Bewegung," Glauben und Verstehen 1 (Tübingen: Mohr, 1993), pp. 1-25, emphasis by author.

14 Briefweschsel, pp. 263, 265. On Bultmann's seminars, we have valuable records: Bernt Jaspert, Sachgemässe Exegese. Die Protokolle aus Rudolf Bultmanns neutestamentlichen Seminaren, 1921-1951 (Marburg: Elwert, 1996).

15 According to the memory of H. Mörchen, recounted by O. Pöggeler, Heidegger in seiner Zeit (Munich: Wilhelm Fink Verlag, 1999), pp. 271-272.

16 Briefweschsel, p. 53 .
} 
gger, for his part, made no mystery of the methodologically atheist character of his (and any) philosophy. There was no quid pro quo. When Gerhard Krüger, in his 1929 survey of Being and Time, saw in it an adequate conceptualization of the situation of man in the world according to Luther, ${ }^{17}$ he was only acknowledging a first truth: man is born without God. A second truth was linked to it: man is born for God. And because the fact of existing - the "factuality" of existence - unfolds doubly, in the universal structures of the existential and in the multitude of the existentiell, then we must be aware of what we are by right of birth in order to reach what we are by vocation. Next, another item must be placed on record: Heidegger's lecture on "Phenomenology and Theology", given in 1927 and 1928, and which waited until 1970 to be first published in France, thanks to an outstanding journal editor Fr. Marcel Régnier, sJ. On the surface, the text relegated theology to the "positive sciences," at the same level as botany or physics. De facto, theology has its ontic positum, Christian preaching. Yet Heidegger took some distance from his text, as he states in a letter to Bultmann on December 18, 1928, that "the positivity of theology, which I believe I have put my finger on, is something other than that of the sciences. Theology is outside the sciences, but in a very different way than philosophy."18 From the published text alone, the philosopher would not have been any more interested in the work of the theologian than he would have been interested in the work of the mathematician - and Heidegger was never interested in the work of the mathematician. Yet the admission just cited is at least an inconvenience for such a view. Theology is a Wissenschaft, in the German sense of the word; it is a matter of positivity (in an existentiel region, but also in texts), yet it alone among all the positive disciplines merits philosophical consideration. And to take measure of what man is before God, one must have taken the measure of what he is without God.

Recognizing the debt that he had towards Heidegger, Bultmann would later write that "all fundamental concepts, in theology, are determined by a preChristian ontological content which we can grasp rationally": ${ }^{19}$ here is the reason why this theologian found in Heidegger his Philosopher. Hans Jonas, a student of Bultmann, went even further: the existential analytic is declared as the "a priori metaphysics of the history of ideas." ${ }^{20}$ In any case, Heidegger would

\footnotetext{
17 Theologische Blätter 8 (1929), pp. 57-64.

18 Briefweschsel, p. 87.

19 Ibid., p. 241.

20 In Augustin und das paulinische Freiheitsproblem (Göttingen: Vandenhoeck \& Ruprecht, 1930, 1965), p. 6. Jonas' application of the Heideggerian analytic to gnosis has an interesting counterpart in E. Steiger's studies of German literature.
} 
say no more about theology. His return to Freiburg coincided with a progressive rejection of Christianity. He responded to this or that criticism of Being and Time. Przywara, who believed he saw in the book a "tragic heroism,"21 would be branded a "charlatan."22 Wilhelm Koepp, who responded to the Heideggerian prevalence of care by the sketch of a philosophy of love, did not even attract a response. ${ }^{23}$ Heidegger would say his final word in a letter to Bultmann from December 16, 1932: "My effort has always been to help theology to awaken to itself from itself." ${ }^{4}$ Since the 1930 lecture "On the Essence of Truth" the philosopher had not really known where he was going. He knew that Being and Time would not be completed (something he had suspected for a long time), ${ }^{25}$ his phenomenological period had come to an end, and it would take his reading of Hölderlin for the question of the "meaning of being" to be raised again. He continued to frequent the Abbey of Beuron, and brought Elisabeth Blochmann to attend the office of Compline with him - he would respond to her astonishment in a letter of September 12, 1929, telling her that Catholicism and Protestantism were certainly an "abomination," ein Greuel, but that Beuron is "the seed of something essential." He would remain strangely faithful to this Benedictine community, and would even give a lecture to the community. But a letter to Karl Löwith, dated from April 19, 1932, declares his rejection of all theology, from Barth to Przywara (Bultmann was not necessarily included!).

Meanwhile, the influence of Heidegger on Bultmann (it doesn't seem that anyone has spoken of an influence of Bultmann on Heidegger ...) had become subject of a polemic. Bultmann had published his Jesus in 1926; in it he tried "to perceive Jesus as a fragment of a history from which we draw our existence, or in regard to which we hold a critical relationship." ${ }^{26} \mathrm{He}$ was working on his commentary on John and entries which had been requested for Kittel's Theologisches Wörterbuch zum Neuen Testament. All this bore, or would have borne, the marks of a work accomplished with Heidegger. But wasn't the theologian mistaken about the nature of his own work? Löwith, a former student of

21 In Stimmen der Zeit 115 (1928), pp. 252-264, at p. 261.

22 April 9, 1929, Briefweschsel, p. 107.

23 W. Koepp, "Merimna und Agape," in H. Dems, ed, Reinhold Seeberg Festschrift (Leipzig: Deichert, 1929), pp. 99-139.

24 Briefweschsel, p. 190.

25 See his confession in David Farrell Krell, Intimations of Mortality. Time, Truth, and Finitude in Heidegger's Thinking of Being (University Park and London: Pennsylvania State University Press, 1986), p. 10o: it was in 1924 or 1925 that Heidegger would have realized that he would not finish Being and Time.

26 Bultmann, Jesus (Munich: Siebenstein Taschenbuch Verlag, 1967), pp. 6-8; trans by L.P. Smith and E.H. Lantero as Jesus and the Word (New York: Scribner's, 1958). 
Heidegger, leveled a brutal accusation. Heidegger's work was in fact a secularization of (Protestant) theology. And in borrowing from Heidegger, a theologian would only unknowingly be taking back possession of what belonged to him anyway. ${ }^{27}$ Other theologians had tried to engage Heidegger by taking position on his terrain. Gogarten, an early companion of Bultmann, had tried a hermeneutics of existence in which existence stumbles against the "You" as its final limit. Brunner had built his concept of an "anchor point" on his interpretation of the Bultmann-Heidegger relation: if the Word was to become audible, the possibility of paying attention to it would have to be inscribed in the logic of existence. And Barth put an end to the debate by confronting Brunner with his "No!" - a no to any theology which seeks to articulate itself through philosophy, whatever it may be. One could add that Bultmann remained without disciples, and that his best students at Marburg - Käsemann, Schlier - returned to a theology which was founded on more than a poorly known "fragment of history" and reinstated a question which was of no interest for Bultmann, that of the "Jesus of History." The taste for a purely existential theology would not die, but as in F. Buri, it would survive independently of any Heideggerian influence. ${ }^{28}$

From the rectorship episode to the mid-193os and beyond, theology - the question of theology - is almost absent from the texts of Heidegger. The preliminary work had certainly been accomplished in the course given at Marburg when Heidegger was putting the last touches on Being and Time: in order to interpret the birth of modern philosophy, whose origins the course traces to Thomas Aquinas (the course ends with a reading of Kant), Heidegger offers nothing less than a strong and detailed preliminary outline of his future critique of the "onto-theological constitution of metaphysics." The course is prior to the famous letter where Heidegger describes himself to Löwith as "a Christian theologian." It ends, in any case, with the God of Christian theology; and it is remarkable that Thomas Aquinas has the status of a founding figure here, and that Duns Scotus, whose ontology is more predisposed to lapse into onto-

27 Karl Löwith, "Phänomenologische Ontologie und Protestantische Theologie" and "Gründzüge der Entwicklung der Phänomenologie zur Philosophie und ihr Verhältnis zur protestantischen Theologie," in Sämtliche Schriften, 3 (Stuttgart, J.B. Metzler: 1985), pp. 1-32 and pp. 33-91, respectively (both texts from 1931).

28 Still, one must note an exception, the "Existential Theology" of John Macquarrie, himself co-author of a respectable English translation of Being and Time: a theology in which non-believing existence is described with the categories of the "inauthentic," and believing existence in those of the "authentic," in a manner which completely overshadows the question of the "meaning of being" (which did not really interest Bultmann), while at the same time making Heidegger a springboard toward the Christian experience. See An Existentialist Theology. A Comparison of Heidegger and Bultmann (London: SCM Press, 1955). 
theology, is not mentioned. The critique of onto-theology, in any case, became a secondary preoccupation when theology gave way to the demi-gods of Hölderlin or to the dead God of Nietzsche. From then on Heidegger found in the "poet of poetry" what became for him a replacement for the Bible. Mythological accents would appear. After the death of the Christian God, the hope in the coming of the "last God" appeared in the "manuscripts on the history of being," written between 1936 and 1941. (Ironically, the research of Bultmann would take an opposite direction, and lead him to a program of "demythologization" of Christianity that Heidegger would explicitly condemn. ${ }^{29}$ ) The mystical readings of the first years at Freiburg rose discreetly to the surface, leading with Eckhart; it is thus legitimate to study the whole "late" philosophy of Heidegger to ask what it owes to these readings, and what it does not. ${ }^{30}$ The event of being represses divine presence, or is uninterested in it.

Heinrich Ott, Barth's student and future successor at Basel, whom Barth sent to study with Bultmann, deserves mention as the first to propose a theological reading of Heidegger which did not limit itself to fragments of Being and Time. Ott, whose Heideggerian readings went as far as the still unpublished texts which made up On the Way to Language, retained Heidegger's critique of metaphysics, and saw in it a movement of thought analogous to Barth's refusal of any analogia entis: thus, being could not play the role of an encompassing category under which one could place God as well as every being. ${ }^{31}$ Overcoming metaphysics was a theological task as well as a philosophical one. ${ }^{32}$ The grand Heideggerian themes are integrated into theological questioning: the world, as Heidegger describes it, is the space where the act of faith is concretely possible (Bultmann would have said the same); being-in-the-world is an existentialontological reality, and frees up, but does not do more than free up, any horizon necessary for the encounter with God. ${ }^{33}$ Philosophy and theology have in com-

29 Letter from August 12, 1964, Briefwechsel, p. 224; A.C. Thiselton has shown that Bultmann had never really killed the Enlightenment man in him. See The Two Horizons. New Testament Hermeneutics and Philosophical Description with Special Reference to Heidegger, Bultmann, Gadamer and Wittgenstein (Exeter: William B. Eerdman's Publishing Company, 1980), §35-40.

30 See also J.D. Caputo, The Mystical Element in Heidegger's Thought (New York: Fordham University Press, 1986). Heidegger, however, never lets himself be influenced without subversion:J. Greisch (see HQD, p. $189 \mathrm{ff}$.) has perfectly shown that the "will to not will" proper to the Heideggerian Gelassenheit cannot be included in the posterity of Eckhart and represents above all Heidegger's final word to Nietzsche. Sein und Denken. Der Weg Martin Heideggers und der Weg der Theologie (Zollikon: Evangelischen Verlag, 1959), p. 144.

32 Ibid., p. 147.

33 Ibid., p. 139 . 
mon that they "think" - theology thus loses the status of positive science that the young Heidegger had assigned to it. The future of thinking, on the other hand, or the pure and simple possibility of thinking, is to be understood as a gift of being. ${ }^{34}$ Further, "theology is phenomenology" ${ }^{35}$ in that it lets itself be led to the thing itself without possessing an external point of view. "For the man who thinks the world and does the work of philosophy," on the other hand, "the experience of nothingness is a moment of his encounter with God." ${ }^{36}$ To the critique of onto-theology, Ott responded that "the being of God signifies an event of unveiling." ${ }^{77}$ God is not a being, nor is he being. And to propose an analogy of proportion, which Heidegger accepted during an annual colloquium of the old Marburgers in 196o: theological thinking is to God what philosophical thinking is to being, without one having priority over the other. In light of more recent Heideggerian texts that he had at his disposal, Ott finally advanced in two directions. On the one hand, the "return to the things," Dinge, which took place in the lectures on "The Thing" and "Building, Dwelling, Thinking," liberated the space in which God could come to experience, more radically than the world conceptualized in Being and Time; the thinking of the Fourfold proved that man exists in constant confrontation with the divine or with an ultimate limit (a point on which Ernst Fuchs would accuse Ott of returning to natural theology). On the other hand, the link of language and the event of being leads us to suggest that theology, if it must be faithful to its mission of "originary and essential thinking,"38 must shelter the experience of prayer and bring it to light. ${ }^{39}$

Decentering the subject in the event of thinking, a thinking that is supremely non-objectifying (something Bultmann had already said), "Heidegger sees the possibility of a theology which really thinks, thus a non-metaphysical theology." It is surely surprising that the youthful enthusiasm of Ott prevented him from perceiving pagan overtones in the "return to the thing." But it will be conceded that Barth's student gave a place to faith without discerning in man any other "anchor point" than his ability to think, whatever it is he thinks, whether being or God. The No! of Barth to Brunner was not followed by any "no" of Barth to Ott, and Ott allowed Barth to put an end to his polemic against the analogia entis in favor of a properly theological thinking of analogy, or of "correspondence"

\footnotetext{
34 Ibid., p. 44.

35 Ibid., p. 48.

36 Ibid., p. 88.

37 Ibid., p. 148.

38 Ibid., p. 171.

39 Ibid., p. 192; cf. "Theologie als Gebet und als Wissenschaft," Theologische Zeitschrift 14 (1958), pp. 120-132.
} 
between God and man in the event of faith. ${ }^{40}$ This likewise put an to end the overly simple formula proposed by Gerhard Ebeling during these years, according to which philosophy is to theology what the law is to the Gospel.

The future did not belong to Ott, whose effort (though widely discussed ${ }^{41}$ ) remained isolated, but rather to the theological reception of Heidegger's research on language. The pioneer in this endeavor was Ernst Fuchs, "who was the first to shift the hermeneutic discussion from the categories of authenticity and inauthenticity derived from Being and Time to the distinction of the late texts of Heidegger between everyday language, trapped in the dilemma of subject and object, and the pure language of being." ${ }^{\text {22 }}$ As with Ott, the refusal of a metaphysical God came first for Fuchs ("to reflect on God today no longer means that one makes him an object of metaphysical research"). ${ }^{43}$ However, unlike Ott, it is in the event of language and not of thinking that God allows himself to be found. At Bultmann's seminar on Luther, Heidegger had said that "the being of God is always grasped (by Luther) as verb." ${ }^{4}$ Fuchs added, "It is not man who has begotten language, it is man who is born from language." 45 "God speaks the word which calls to being because he himself wanted to be 'as' word."46 As grasped in his word, the being of God is defined thus as an "event of a true proximity given against the background of a originarily experienced distance." 47 In the beginning, in good Lutheran terms, comes justice by works, which has its correspondent in thinking about God in terms of objectivity/subjectivity. In the element of faith, on the other hand, comes an "event of language," to be understood as an event of salvation, Heilsgeschehen, which declares God's love for man. The "new hermeneutics" is thus hermeneutics of a language of love which illuminates every other language. Heidegger once again participated in this period of theological discussion with interest. He attended the seminar of Fuch's twin brother in theological hermeneutics, Gerhart Ebeling, ${ }^{48}$ and attended the colloquium of old Marburgers in October 1963 (H.G. Gadamer was also there, and a new age of hermeneutics began). Com-

\footnotetext{
$40 \quad$ See ibid., p. 29.

41 See for example J.M. Robinson and J.B. Cobb Jr., The Later Heidegger and Theology (New York: Harper \& Row, 1963).

J.M. Robinson, in The New Hermeneutic: New Frontiers in Theology, Vol. II (New York: Harper \& Row, 1964), p. 49.

44 Briefwechsel, p. 271.

45 Fuchs, Hermeneutik, p. 63.

46 Ibid., p. 71.

47 Ibid., p. 72.

48 See Briefwechsel, pp. 286-305.
} 
menting on Luther in the presence of Ebeling, Heidegger gave a neat reminder of Lutheran orthodoxy: "Is it really as a rational being that man is a hearer fit for the preached word? Does not the verbum fidei rather encounter man sine preambulis et contra rationem?"49 One may recall here the striking maxim in On the Way to Language: "language speaks," die Sprache spricht. The primacy of the word over the one who receives it and transmits it is what Heidegger taught Fuchs, Ebeling, and their other disciples.

This was almost the last word of Heideggerian influence on (initially German) theology. Fuchs and Ebeling ${ }^{50}$ surely continued their work. In 1975, Eberhard Jüngel's God as Mystery of the World contained a dialogue with Heidegger. In the Catholic field, Hans Urs von Balthasar devoted an in-depth study to the ontological difference - a study where he indeed concedes much to Heidegger. However, in 1961 an edited work by Wolfhart Pannenberg appeared, entitled Revelation as a History, which sounded the death knell for existential interests. The God of theologians was no longer the one in Bultmann who allows us to attain authentic existence, but the one whose passage in history we can easily perceive. The philosophical influence, for its part, was put to work where one might have expected: in the recovery and evaluation of the onto-theological critique, and, by extension, in the examination of the "death of God." Philosophizing beyond metaphysics, and then, under the influence of Derrida, proceeding to a deconstruction of metaphysics, the leitmotifs here were sometimes associated with structuralist projects..$^{51}$ Annemarie Gethmann-Siefert had found the right formula for the Heideggerian conception of theology:52 theology is, for Heidegger, only "hermeneutics of a witnessed/testified experience," Hermeneutik bezeugter Erfahrung, whether it be New Testament theology or the theology of Hölderlin. However, a synthesis was yet to be accomplished, or attempted. And beyond Heidegger's interest in theology, the question of God, whether it be theological or philosophical, still had to be tackled head on. This was the project of the colloquium which we have the honor of reintroducing here.

On the work of the participant at the symposium of 1979, there is nothing to retell, and having reread the texts after thirty years, I content myself

\footnotetext{
49 Ibid., p. 297.

50 On Fuchs, see J.B. Brantschen, Wege und Umwege heutiger Theologie. Zu einer Ortsbestimmung der Theologie von Ernst Fuchs (Freiburg/Schweiz: Universitätsverlag, 1974). On Ebeling, see R. Marie, Parler de Dieu aujourd'hui. La théologie herméneutique de G. Ebeling (Paris: Cerf, 1975).

51 For example, A. Delzant, La communication de Dieu (Paris: Cerf, 1978), pp. 9-17 and passim.

52 In Das Verhältnis von Philosophie und Theologie im Denken Martin Heideggers (FribourgMunich: Karl Alber, 1974), p. 240.
} 
with observing how perfectly timeless they are, thus, a rare achievement. As it would be pointless to call into question the principal assertions, I will content myself with taking note of them. Ricoeur's opening lines should be inscribed in every memory: "What has often astonished me in Heidegger is that he has, it seems, systematically eluded a confrontation with the entirety of Hebraic thought." It could not have been better said. And the same affirmation is found in the contribution of Bernard Dupuy, underlining on the one hand Heidegger's forgetting of creation, ${ }^{53}$ and on the other hand the forgetting of the biblical phenomenon par excellence, the relation between God and the people of God. Beaufret says the same thing, from another starting point: "Being in the Greek sense does not open any possible access to the God of the Bible, but to a completely different 'theology' than that of the creator of heaven and earth." F. Fédier provides an important qualification, which anticipates what we now know from the courses of the young Heidegger, at that time still unpublished: "Perhaps the thought of God is not the summit of the Christian life." One could refuse the proposition: either to think God "without being" and as agapé that no ontology could trap in its net (Jean-Luc Marion), or to pass from the metaphysical thinking of God as ens to a post-metaphysical and eschatological thinking of God as posse (Richard Kearney). (But we could also denounce "the illusion that consists of wanting to think love, and by love, God, 'outside' the question of being" - Maria Villela-Petit.) A position just as radical, or perhaps even more, is found in Joseph S. O'Leary: "For my part, I would like to defend the possibility of a dialogue in which faith and thinking would be differentiated from each other without allowing either to situate and define the other in terms of its own categories. There would thus be no Christian theory of being, nor any possibility of thinking phenomena of Christian revelation in light of Ereignis." ${ }^{54}$ With the consequence that man must be thought as an essentially "pluralist" animal. I note these few contentions with the sole purpose of inviting a more thorough read.

Especially considering that only some of Heidegger was accessible in 1979, it is remarkable that nothing published since then has called into question the work done at the Irish College. Other ideas were relegated to the archives and would remain there, first of all Tillich's conceptualization of God as Beingitself and as Ground of Being. Macquarrie, in 1966, had proposed an "existential

53 On the God "cause," see G. Poltner, "Martin Heideggers Kritik am Begriff der creatio," in H. Vetter, ed, Heidegger und das Mittelalter (Frankfurt: Peter Lang, 1999), pp. 61-8o.

54 Cf. A.B. Come, "Advocatus Dei - advocatus hominis et mundi," in Robinson and Cobb, eds, The Later Heidegger and Theology, p. 119: "If the Christian must live under the dictum, simul justus et peccator, he must also continue to acknowledge, simul christianus et paganus." 
concept of God" as holy being, or as an "incomparable who lets be and is present and manifest to us": $: 5$ these concepts certainly do not stand up to the reading of texts. Yet the work of 1979 still had to be read more precisely once the unpublished manuscripts appeared, and some propositions which were inevitably at times too clear-cut had to be nuanced.

The first domain where nuance imposed itself was that of the critiques of onto-theology. Is every thought attributing being to God ipso facto metaphysical? Jean-Luc Marion said this in 1979 and repeated it in the manifesto God Without Being. More cautious texts followed to affirm the apophatic character of esse in Thomas Aquinas and Augustine. ${ }^{56}$ From the point of view of analytic philosophy, Frédéric Nef has claimed onto-theology simply "cannot be found" in the history of philosophy. ${ }^{57}$ This judgment is certainly excessive. Yet where does one encounter metaphysics in its pure form? The current state of research leads us to suggest a name: Suarez. A general theory of beingness, a dispensing of being to all beings according to their respective merits, onto-theology does not appear here out of nothing, but can be identified as the form which draws as perfectly as possible the criticism of Heidegger - who does not seem to have been himself aware of this. ${ }^{58}$ Contemporary to Being and Time (dating back to 1932), the construction proposed by Przywara in his Analogia entis falls under the same critique: that of a God who is summus ens, even if his supremacy is exercised in a dialectic of similarly and dissimilarity where one cannot pose the similarity without admitting an even greater dissimilarity. One must

55 Principles of Christian Theology (London: SCM Press, 1966, 1977), pp. 104-122, "Being and God." [Italicized words originally written in English. - Trans.]

56 "L'onto-théo-logie de saint Thomas," Revue thomiste 1 (1995), pp. 31-66, reprinted in Dieu sans l'être (Paris: Presses Universitaires de France, 1991), pp. 279-332, trans. Thomas A. Carlson as God Without Being (Chicago: University of Chicago Press, 2012), pp. 199236; "Addition. Idipsum ou le nom de Dieu," appendix of Au lieu de soi. L'approche de saint Augustin (Paris: Presses Universitaires de France, 2009), pp. 388-414; trans. J.K. Kosky, In the Self's Place. The Approach of Saint Augustine (Stanford: Stanford University Press, 2012), pp. 289-3o6.

57 See Qu'est-ce que la métaphysique? (Paris: Gaillmard, 2004), pp. 231-411.

$5^{8}$ Heidegger of course commented that Suarez "is the thinker who has been the most powerful influence on modern philosophy" (GA 24, p. 112). But between the Middle Ages and Suarez, he does not see any rupture, or for that matter a radicalization. In the same section of the course, Heidegger proceeds as well to his most precise treatment of Duns Scotus, where it must be if God, as an infinite being, does not escape the suspicion of onto-theologization by his very infinity. On this point, see Olivier Boulnois, "Heidegger, l'ontothéologie et les structures médiévales de la métaphysique," Quaestio 1 (Turnhout, 2001), pp. 379-406. See as well A. K. Wucherer-Huldenfeld, "Zu Heideggers Verständnis des Seins bei Johannes Duns Scotus im Skotismus sowie im Thomismus und bei Thomas von Aquin," in H. Vetter, ed, Heidegger und das Mittelalter, pp. 41-59. 
take care, however, for metaphysics is appropriating here a text untainted by any metaphysical temptation, the canon of the Fourth Lateran Council on the knowledge of God..$^{59}$ In this text, any reference to ens or to esse is absent. The relation in question is that of creator to creature and not that of ens increatum to ens creatum. Przywara incurred the anathema of Barth. But it was a Barthian, Jüngel, who recognized that the analogy of being reunites God and the world under the same concept and runs the risk of producing an "idol," in the lexicon of Jean-Luc Marion, or a God dependent on a theory of being, but that the language used by Lateran IV is not an invention of the Antichrist. It may be that the history of philosophy and theology is more a subject to a metaphysical temptation than a reign of metaphysics.

The publication of the first course at Freiburg proves, if there were need to do so, that Heidegger by all accounts was less interested in God than in Christian experience, and then in a pagan-flavored experience. The publication of the "Natorp Report," a manuscript which allowed Heidegger to receive his status as an extraordinary professor at Marburg, was prefaced by Gadamer, who called the text a "theological writing of his youth." ${ }^{0}$ The same could be said of the courses dedicated to the introduction to phenomenology of religion, Augustine and Neoplatonism, and the sketches of a course on the philosophical foundations of medieval mysticism. ${ }^{61}$ The project is hermeneutic, in the vague sense of the term: understanding Christian experience. Reading the first Christian texts matters, in the first-mentioned of these courses, because it allows the temporality proper to Christian experience to come to light, to the point of saying "Christianity lives time itself." ${ }^{62}$ The reasons for a fruitful encounter with Bultmann were there. There is more. Heidegger is interested in Christian experience, but it is not certain that he was really interested in Christianity. There are several reasons for this.

The first, which has not yet been the object of in-depth research, is the link between Christianity and Latinism. What is Greek, Heidegger emphasizes,

59 Denzinger-Schönmetzer, Enchiridion symbolorum (Freiburg, Basel, Rome \& Vienna: Herder, 1997), p. 806.

6o According to the author of the preface, "the importance of this manuscript resides today for us in the fact that Heidegger, even then, was fully engaged in research. And what he was researching was an adequate interpretation and an anthropological intelligence of the Christian consciousness." See "Heideggers 'theologische' Jugendschrift," Dilthey-Jahrbuch für Philosophie und Geschichte der Geisteswissenschaften 6 (1989), pp. 228-234, at p. 228.

$61 G A, 60,1995$. On the Fondements philosophiques de la mystique médiévale, see the commentary of S. Camilleri, Phénoménologie de la religion et herméneutique théologique dans la pensée du jeune Heidegger. Phaenomenologica, 184 (Dordrecht: Springer, 2008). 
degenerates in the hands of the Latin language and culture. The only Christianity that Heidegger had known - the only one he had read - is Latin or from the Latin world. And the suspicions that perpetually plague the Latinization of Greek thought could, it seems, only echo Harnack's quest to dehellenize Christian thinking; Heidegger would instead ask us to delatinize it.

The second reason, which we have already mentioned, is that the Creator God of Christianity (and of Judaism) appeared to Heidegger as a God implicated in advance in the process of "fabrication." We know that the title "creator" was only applied quite late to man, by Nicolas of Cusa and then Giordano Bruno. Yet Heidegger either does not know this or refuses to recognize it. The ens increatum thus opens a space for the technological vision of the world to rush in. There is no shortage of responses, among which one must recall the most remarkable: the Hebrew bible contains the word bâra', "to make," of which God alone could be the subject - as well a correlate which emphasizes the human work whose principal result is the fabrication of idols. To restore to creation its biblical sense would allow it to be dissociated from the destiny of metaphysics.

A third reason, finally, is the Heideggerian obfuscation of theology in favor of what might be called the "religious," which is incarnated in the demi-gods of Hölderlin as well as in the divinities or the last god, and whose experience takes place somewhere other than in the tonalities of Christianity. In 1979 Jean Greisch highlighted the contrast of Heideggerian serenity and Christian hope. His work subsequently led him, if not to preserve for Heidegger a central place in the philosophy of religion, at least to underline precisely what distinguishes his Gelassenheit from its apparent parallel with Eckhart. ${ }^{63}$ In the post-phenomenological texts of Heidegger, the question of God has no room left, except when he deals with the destruction of metaphysics. And if similar questions arise outside of this frame, they address religious hermeneutics, in the age of nihilism and in order to escape nihilism, but without the help of the Christian God. As for the Beiträge (published in 1989), Wilhelm Weischedel spoke of a "theology from the background of the history of being." The God who appeared in any case justified the protests of Jean-Luc Marion in 1979: this God is governed by the history of being, and indeed governed by being; the cri-

63 See “'Warum denn das Warum?' Heidegger und Meister Eckhart:Von der Phänomenologie zum Ereignisdenken" in N. Fischer and F.W. von Herrmann, eds, Heidegger und die christliche Tradition (Hamburg: Meiner, 2007), pp. 129-147. On Heidegger's relation to Eckhart, see also H. Helting, "Heidegger und Meister Eckehart," in P.L. Coriando, ed, "Herkunft aber bleibt stets Zukunft." Martin Heidegger und die Gottesfrage (Frankfurt: Klostermann, 1998), pp. 83-100. 
tique of onto-theology could thus turn back against the "divine God" - to end in an onto-theology which is certainly not that of metaphysics, but to which Heidegger seems doomed to sacrifice to despite his most express intentions.

Canonically philosophical questions, canonically theological questions: let readers of this 1979 Colloquium be advised that the distinction matters little to a critical reading of Heidegger. God belongs neither to the philosopher, nor to the theologian, nor to the religious man. At the Irish College, Stanislas Breton concluded his paper by conceding, "It matters little that one calls himself a philosopher or theologian; the spirit who blows where it will will recognize its own." Later work has allowed us to clarify what this distinction entails. ${ }^{64}$ Heidegger's position towards Christianity has been the object of an important treatment under the pen of Didier Franck. ${ }^{65}$ Other work will inevitably follow. What was said and written thirty years ago has stood up to the many pages of previously unpublished material. Whether to make it available for re-reading or to recommend it, its republication was entirely necessary.

\section{Translated by Stephanie Rumpza}

64 See above all Philippe Capelle, Philosophie et théologie dans la pensée de Martin Heidegger (Paris: Cerf, 1998). Also, two useful syntheses: Schaeffler, Wechselbeziehungen, pp. 22926o, and Gert Hummel, Die Begegnungen zwischen Philosophie und evangelischer Theologie im 20 Jahrhundert (Darmstadt: Wissenschaftliche Buchgesellschaft, 1989), pp. 221-332. Appearing shortly afterwards, see Emilio Brito's text, under the accurate title Heidegger et l'hymne du sacré (Leuven: Leuven University Press, 1999). Brito's presentation confirms, among other things, and in detail, what P.M. Hederman was quite right to object in 1979, that "the thinking of the sacred is much more subtle than Levinas realizes," HQD, p. 316.

65 Heidegger et le christianisme. L'explication silencieuse (Paris: Presses Universitaires de France, 2004). 